\title{
Law Enforcement of Foreign Workers Abusing Immigration Residence Permit: Case Studies on Energy and Mining Companies
}

\author{
M. Alvi Syahrin \\ Immigration Polytechnic \\ Directorate General of Immigration \\ Jakarta, Indonesia \\ ma.syahrin@gmail.com
}

\author{
Irsan \\ Faculty of Law Sriwijaya University \\ Palembang, Indonesia \\ irsanrusmawimuchtar@yahoo.com
}

\begin{abstract}
The development of globalization brings various impacts on labour and immigration law in Indonesia. The most frequent immigration violations are the abuse of immigration residence permits by foreign workers, especially in energy and mining companies. The Turnkey Project Mangement between Indonesia and China has a systemic impact, especially on foreign capital ownership, infrastructure, and labour. Examples of cases of foreign workers in energy and mining companies are located in Kendari City, Southeast Sulawesi Province. Based on data released by the Ministry of Manpower as of April 6, 2018, there are at least 927 Chinese who work illegally in a number of mining companies. The foreign workers is mostly employed in Virtue Dragon Nickel Industry with a total of 632 people. Another case also occurred in Lahat, South Sumatra Province. There are at least about 671 Chinese citizens who work illegally in PT. Priamanaya Energy. Of these, at least $90 \%$ of foreign workers work in Indonesia in the energy and mining sectors. Most of them are illegal foreign workers who do not have a Limited Stay Permit Working from the Immigration Office and Permit for Working Foreign Workers from the Ministry of Manpower. Most of their modes are to use Visa Free Visa Policy that should not be for work. Based on the results of the discussion, can be explained as follows. First, the process of law enforcement on the abuse of immigration residence permit is done in two ways, namely Immigration Administrative Act and Investigation (Pro Justitia). Immigration Administrative Action is arranged in Article 75 paragraph (2) on Law of the Republic of Indonesia Number 6 of 2011 concerning Immigration. This action takes place outside the judicial process and is subject to immigration administrative violations. Meanwhile, the Investigation is a legal action from the Civil Servant Investigator of Immigration against the alleged criminal act of immigration. The case of improper immigration permit abuses by foreign workers is regulated in Article 122 of Law of the Republic of Indonesia Number 6 of 2011 concerning Immigration. Second, in practice officers more often apply immigration administrative measures in resolving immigration residence cases. Based on the Performance Report of Directorate General of Immigration of 2017 stated that there are 1,992 Chinese conducted Immigration Administrative Actions, in the form of Deportation. About $80 \%$ of them are illegal workers in the energy and mining sectors. Investigative Actions is rarely implemented, as it is considered ineffective, requiring a relatively long time in the process. Then, budget allocations are still inadequate and human resources Civil Servant Investigator of Immigration is very limited evenly in all regions. In 2017, the number of investigative actions is only 286
\end{abstract}

people. It was very different from the number of immigration administrative actions. This is because law enforcement on the abuse of immigration stay permits is often limited by the number of Immigration Officers and the lack of coordination and cooperation among cross-sectoral agencies. In addition, the lack of immigration Civil Servant Investigator of Immigration that controls foreign languages other than English and limited operational support facilities. Finally, there are still many uncooperative people sending out reports or complaints about the existence or activities of troubled foreign migrant workers.

Keywords - law enforcement, foreign workers, energy and mining companies

\section{INTRODUCTION}

In globalization and free trade era has brought an impact on increasing the high traffic of people. This phenomenon has become the concern of countries in the world including Indonesia for all the countries in the world[1]. They have the authority to regulate the traffic of people who will be entering and exiting the territory of his country[2]. The impact that arises increasingly varied. Each country addressing carefully and wisely so as not to negatively affect the business sector[3] or relationships that are not harmonized between countries. So, the guidelines are needed to relate between each other may be adapted to the social and political conditions each of the countries[4].

The impact of the globalisation are narcotic drugs trading, terrorist, human trafficking, people smuggling, money laundering, and others. From the example of the negative effects of the above, it can be classified as organized crime or action is often called the Transnational Organized Crimes[5]. That crimes not only threatens the sovereignty of Indonesia itself, but also threatening and disturbing peace and sovereignty throughout the all state in the world[6].

To minimize the negative effects, then needed an agency that regulates the problem of the influx of people into the region out of Indonesia, namely Directorate General of Immigration.

Directorate General of Immigration is an agency which regulates the issue of influx of people came out to the territory of Indonesia. Article 1 point 1 Law of Republic of Indonesia Number 6 of 2011 concerning Immigration, states 
that: "Immigration shall mean the traffic subjects of people that enter or exit the Indonesian Territory and the control in order to safeguard the enforcement if state sovereignty."

Based on international law, field of immigration (outgoing traffic) a country is right and authority of a country. In other words, immigraton act is one of the indicators of a country's sovereignty[7]. Immigration also have a role in different areas of the life of a nation and a country such as economics, politics, law, and security[8].

But in the last few years, there has been an increase in violations of immigration as a result of the influence of globalization. The most frequent immigration violations are the abuse of immigration residence permits by foreign workers, especially in energy and mining companies. The Turnkey Project Mangement between Indonesia and China has a systemic impact, especially on foreign capital ownership, infrastructure, and labour. Examples of cases of foreign workers in energy and mining companies are located in Kendari City, Southeast Sulawesi Province. Based on data released by the Ministry of Manpower as of April 6, 2018, there are at least 927 Chinese who work illegally in a number of mining companies. The foreign workers is mostly employed in Virtue Dragon Nickel Industry with a total of 632 people. Another case also occurred in Lahat, South Sumatra Province. There are at least about 671 Chinese citizens who work illegally in PT. Priamanaya Energy[9]. Of these, at least $90 \%$ of foreign workers work in Indonesia in the energy and mining sectors. Most of them are illegal foreign workers who do not have a Limited Stay Permit Working from the Immigration Office and Permit for Working Foreign Workers from the Ministry of Manpower. Most of their modes are to use Visa Free Visa Policy that should not be for work.

Based on the background above, problems in this research are formulated as follows:

1. How is law enforcement against foreign workers who commits criminal acts of abuse of immigration residence permits?

2. What are the obstacles faced law enforcement in foreign workers who commits criminal acts of abuse of immigration residence permits?

\section{A. Methodology}

\section{Method Approach}

The formulation of the problem shows that the research is done by approach of juridicial normative approach, where the normative jurisdiction is to examine a legal problem and make the settlement through the applicable legislation[10].

\section{Research Spesifications}

The spesification of this study is descriptive analysis to provide an overview of the real facts along with an accurate analysis of laws and regulations that can be used as material analysis related to visit visa philosophical exemption policy[11][12].

\section{DISCUSSIONS}

A. Law Enforcement Against Foreign Workers who Commits Criminal Acts of Abuse of Immigration Residence Permits

Law enforcement is officials action by people concerned in accordance with their respective authority according to the rules of the applicable law[13][14][15]. In the immigration task implementation. The overall immigration rules applied to all of Indonesian and foreigners. It is intended to create a deterrent effect to offenders of immigration criminal acts in Indonesia. Immigration law enforcement is very important, because immigration is closely related to the sovereignty of a country[16]. With its strict law enforcement, then the integrity and Indonesia sovereignty will be respected and appreciated by other countries.

Immigration law enforcement dedicated to the problems of:
a. impersonation;
b. accountability of the sponsor;
c. double Passport ownership;
d. involvement in violations of immigration rules.

Whereas, immigration law enforcement against foreigners dedicated to the problems of:

a. counterfeiting of foreigners identity;

b. foreigners registration and giving of the foreigners supervision book;

c. abuse of immigration residence permits;

d. illegal entry;

e. raids;

f. insecurity of immigration is geographically in the Balkans.

\section{The Immigration Administrative Actions}

Immigration Administrative Action, which refers to Law of Republic of Indonesia Number 6 of 2011 concerning Immigration, Article 1 point 31 stating that the administrative sanctions defined Immigration Officials against foreigners outside the judicial process. Law of Republic of Indonesia Number 6 of 2011 concerning Immigration, Article 75 paragraph (1) determine the immigration administrative action if the of foreigners residing in the territory of Indonesia that do the activities are dangerous and jeopardize security and allegedly worth public order or does not respect or does not comply with the legislation

Law of Republic of Indonesia Number 6 of 2011 concerning Immigration, Article 75 paragraph (2) determine the immigration administrative action, consists of:

a. inclusion in the list of watchlisted;

b. limitation, amendment or cancellation of the residence permit;

c. prohibition to be on one or several specific places in the territory of Indonesia;

d. having to live in a certain place in the territory of Indonesia;

e. the imposition of the cost burden; and/or

f. deportation from the territory of Indonesia.

As a law enforcement instrument, Immigration Law contains a clause 'denied to entry' not only against foreigners, but also against Indonesian. Although the process and requirements to set 'denied to entry' for Indonesian is tight enough but the norm is clearly contrary to human rights.

Further, countries have the power to expel and deport the foreigners, such as the power to denial of granting an entry permit. It is considered as a thing that is attached to the territorial sovereignty of a country[17]. The rules of the 
existence and activities of foreigners in a country is the essence of territorial sovereignty inherent in a country, then the state has the right to determine the limitations and to the existence of an activity that may or can be done by foreigners.

Immigration law enforcement started from surveillance against people who traffic in and out of the territory of Indonesia and the supervision of foreigners in the territory of Indonesia. Immigration officers authorized to perform administrative actions against the immigration of foreigners residing in the territory of Indonesia who conduct harmful activities and allegedly endangering the security and worthy of public order or is disrespectful or not comply with laws and regulations.

The authority to establish immigration administrative actions exist at the Head of the Immigration Office, at the level of monitoring and control are on the Coordinator at any Region Office of the Ministry of Justice and Human Rights, and at the centre stage are on the Director General of Immigration (cq. Director of Investigation and Immigration Action[18]. Although the settings regarding the existence and activities of foreigners is an instrument of state sovereignty enforcement, Law of Republic of Indonesia Number 6 of 2011 concerning Immigration also regulates the rights of foreigners are exposed to the action of immigration to apply for mind hierarchically. It turns out that immigration law also pay attention to the issue as part of human rights[19].

The immigration administrative actions that most often given to immigration offenders is deportation. Deportation is forcibly act to removing foreigners from the region of Indonesia. The process of deportation conducted include: do proceedings news to the foreigners who violated immigration rules are accompanied by translators, and also brought in a Embassy of the foreigners in question as a confirmation of the truth of the stranger's identity in the form of a passport, do some checking the validity of visas issued at the Embassy of the Republic of Indonesia nor visa is issued at the time of the foreigners arrived in Indonesia, then make a deportation decision letter[20].

The deportation decision issued by the immigration officers, that is the Head of the Immigration Office and the decision must be given to foreigners who are subject to immigration action no later than 7 (seven) days from the date of the determination. As long as foreigners waiting process of deportation, strangers are placed in the immigration detention rooms.

Law of Republic of Indonesia Number 6 of 2011 concerning Immigration, Article 1 paragraph 34 states that the immigration detention rooms is a temporary shelter for foreigners who are charged immigration administrative actions. Article 44 paragraph 1 states that any foreigners who reside in the territory of Indonesia can be placed in the immigration detention rooms without having a valid residence permit, or in order to wait out the deportation expulsion process to the region of Indonesia.

Immigration detention rooms meted against the Immigration of foreigners does not have a status of state custody home, but its management including her treatment towards its inhabitants can be likened to prisons. It is explained that when not included in state custody homes or other form of detention then the consequences that will come up is the absence of the prisoner's pieces will be accepted by the foreign person upon detention himself in the verdict[21].

Examples of cases that have occurred against a chinese stranger named Chen Qinpeng, Passport Number E58942114 and Jing an Cilu, Passport Number E37538042. Chen Qinpeng and Jing Cilu had committed the immigration crime of, where both entry into Indonesia through the SoekarnoHatta Airport on September 162015 using a Visa on Arrival. Against defendants who have committed a criminal offence of abuse of a residence permit who violates the provisions of the immigration legislation, as it concerned only have permission to visit and vacation not to work. But in fact the defendant work doing training towards the employees of PT Graha Sarana Radema that working on drilling projects for the installation of a gas pipeline belonging to PGN in Bandar Lampung. So the defendant alleged immigration violation as referred to Article 122 letter (a) jo Article 75 paragraph (2) letter (a) and (b), and (f) Law of Republic of Indonesia Number 6 of 2011 concerning Immigration and to the concerned subject to immigration administrative actions in the form of denied, the cancellation of the residence permit, and deportation.

Theoretically, immigration officers should enforce Law of Republic of Indonesia Number 6 of 2011 concerning Immigration. Against foreigners who do abuse the visa should be in deportation. However in practice often constrained against the cost against the repatriation of foreigners so many foreigners who piled in Immigration Detention House[22].

At the time of the process of repatriation of foreigners conducted surveillance of departure by immigration officers until an Immigration Checkpoint, and then enumerated the sign of refusal passport by immigration officers at the Immigration Checkpoints both in the airport as well as ports and repatriated the foreigners.

\section{Investigation}

Immigration investigation is handling a immigration criminal act through the judicial process, which is included in the criminal justice system[23]. Investigation or often called pro justisia act granted to a foreigner who commits a criminal act listed in Law of Republic of Indonesia Number 6 of 2011 concerning Immigration. Such action in the form of the investigation against the suspect and evidence pertaining to crime and immigration do, take action first on the scene, performing detention actions against a foreigner, do the search, seizure and examination of places, objects, documents, letters relating to the criminal offence of immigration, calling witnesses and suspects, with the creation of news his show every legal action being undertaken[24][25].

Foreigner when the hand was caught committing a immigration criminal act, then the investigator can directly perform actions as set forth in the Article 5 paragraph (1) letter b Criminal Procedure Code, namely:

a. Arrest, the ban on leaving the site, searches and seizures;

b. Inspection and seizure of letters taking fingerprints and a photograph of a person;

c. Carry and confronts someone to investigators. 
This action was carried out by Immigration Civil Servant Investigators. Immigration Civil Servant Investigators, authorized by law to perform immigration law enforcement against violations of immigration a criminal offence. Immigration Civil Servant Investigators do is coordinate with Police Investigator in terms of the notice of commencement of investigation, as Coordinator and supervisor of Immigration Civil Servant Investigators as the provision in Article 107 paragraph (2) Criminal Procedure Code.

Committed action against foreign nationals who do immigration criminal act, carried out by way of calling, checking, rummage, capture or detain someone suspected of doing the crime of immigration. Where reports of the society against the foreign citizen who commits a criminal act are helpful in immigration law enforcement[26]. The role and the public is still very minimal. Things ini is evident from the lack of reports of society against the infringement of immigration law.

The checks carried out is an activity to obtain information, and clarity of the suspect nor the witnesses and evidence as well as on elements of immigration a criminal offence has occurred, so the position or the role of the person as well as evidence in the Immigration Act be clear and bright[27]. The basic consideration is examination conducted immigration report of the incident, the news of the proceedings on the scene details, news of the event capture, immigration, etc. Completion and submission of dossiers is the end of the process of investigation of immigration a criminal offence.

Practically, investigation rarely implemented. This is because it takes a relatively long time in the process, and the allocation of the budget is still not adequate and equitably in all areas and the Immigration Civil Servant Investigators resources are very limited if compared with the Police Investigators[28]. So that officers in the field lore chose remedy immigration administrative action, like deportation to region country.

The purpose of surveillance against foreigners coming into Indonesia is in keeping state sovereignty. So from that in enforcing the Law of Republic of Indonesia Number 6 of 2011 concerning Immigration, immigration should conduct surveillance and monitori against foreigners coming into Indonesia since foreigners were at the airport as well as in the harbor where in passport visa in checking more thoroughly[29]. If they found irregularities or suspicion against foreigners, then immigration officer conducting the interview against the motive and purpose of people foreign entry into Indonesia.

Then the regions to be visited in the data and put into the system directly connected with the system contained in the regional immigration offices where foreigners would visit. So if the foreigner does not report its existence in an area to the local immigration office, immigration officers can retains the data of foreigners entering the territory. The existence of such data immigration officers can more easily conduct surveillance against foreigners residing on its territory.

B. The Obstacles Faced Law Enforcement in Foreign Workers who Commits Criminal Acts of Abuse of Immigration Residence Permits

The ultimate goal of the enforcement of the law against the crime of abuse of immigration permits is the obedience of law and order for foreign nationals who enter the territory of Indonesia. To achieve this very important how the role of Immigration in making foreign nationals residing in Indonesia against law abiding[30].

Each activities implementation definitely have obstacles even though it has been well planned, as well as enforcement of the law against the crime of abuse of immigration permits have barriers. The following barriers implementation of law enforcement against criminal acts of abuse of immigration permits:

1. Surveillance and monitoring against the presence of foreigners in the territory of Indonesia conducted by Immigration authorities still have not been able to do the maximum supervision to know what activity or the existence of aliens. This is due to the number of immigration officers felt less;

2. Lack of coordination and cooperation between related cross-cutting agencies particularly the immigration authorities as implementing authorities of existing legislation;

3. Lack of Immigration Civil Servant Investigators that master a foreign language other than the english language. Though generally a stranger who examined do not master the english language. So as to conduct the examination of the case is being handled by Immigration Civil Servant Investigators against foreigners from certain countries must require a linguist or translator. It is troublesome in conducting the inspection. For example, in the examination of foreign origin in Afghanistan, China, Japan, Egypt, or of other countries who are unfamiliar with the english language;

4. The limited number of operational support, as a means of funding operations, transportation, and communication, as well as the firearm of which there is very limited. This leads to the Immigration Civil Servant Investigators performance;

5. The existence of uncooperative, no attitude, and less education, lack of socialization in the legislation community, the presence of the factor of interest the business of the parties concerned, and the existence of a presumption of community itself too extolling everything comes from a foreign country[31]. Community participation until recently perceived is still very low. Reports or complaints from the public about the existence or activities of the foreigners there were still very few. This can be caused as society itself, which being apathetic, or because of the lack of understanding of the consequences yet it does socialization Law of Republic of Indonesia Number 6 of 2011 concerning Immigration up to the corners of the countryside;

6. A relatively takes long time in completing the docket. Each matter of immigration usually takes at least 3 (three) months to resolve the matter.

In the implementation, Directorate General of Immigration, operationally meet the demands of the changing times of the reformation. So also in the legal system, which in practice was in accordance with a simple procedure with the principle of public accountability that is based on the principle of transparency (openness)[32]. Immigration law enforcement does not run as expected 
without the appropriate human resources, the legal system is clear and adequate means, in the absence of law enforcement apparatus that immoral and integrate high then the purpose of the the establishment of the immigration act that there would not be achieved optimally[33].

Based on the research and analysis of the barriers in law enforcement against foreign workers who perform criminal acts of abuse of immigration permits in some areas are the number of immigration officers who conduct surveillance and monitoring against the presence of foreigners is considered less, lack of coordination and cooperation between agencies are cross-cutting, lack of Immigration Civil Servant Investigators, master a foreign language other than the language of english, the limited number of means of supporting operational and cultural society the not cooperative where reports or complaints from the public about the existence or activities of the foreigners there were still very few.

\section{CONCLUSIONS}

Based on the results of the discussion, can be explained as follows.

1. The process of law enforcement on the abuse of immigration residence permit is done in two ways, namely Immigration Administrative Act and Investigation (Pro Justitia). Immigration Administrative Action is arranged in Article 75 paragraph (2) on Law of the Republic of Indonesia Number 6 of 2011 concerning Immigration. This action takes place outside the judicial process and is subject to immigration administrative violations. Meanwhile, the Investigation is a legal action from the Civil Servant Investigator of Immigration against the alleged criminal act of immigration. The case of improper immigration permit abuses by foreign workers is regulated in Article 122 of Law of the Republic of Indonesia Number 6 of 2011 concerning Immigration.

In practice, officers more often apply immigration administrative measures in resolving immigration residence cases. Based on the Performance Report of Directorate General of Immigration of 2017 stated that there are 1,992 Chinese conducted Immigration Administrative Actions, in the form of Deportation. About $80 \%$ of them are illegal workers in the energy and mining sectors. Investigative Actions is rarely implemented, as it is considered ineffective, requiring a relatively long time in the process. Then, budget allocations are still inadequate and human resources Civil Servant Investigator of Immigration is very limited evenly in all regions. In 2017, the number of investigative actions is only 286 people. It was very different from the number of immigration administrative actions. This is because law enforcement on the abuse of immigration stay permits is often limited by the number of Immigration Officers and the lack of coordination and cooperation among cross-sectoral agencies. In addition, the lack of immigration Civil Servant Investigator of Immigration that controls foreign languages other than English and limited operational support facilities. Finally, there are still many uncooperative people sending out reports or complaints about the existence or activities of troubled foreign migrant workers.

\section{RECOMMENDATIONS}

There are some advice to can be input as follows:

1. Immigration officers should increase surveillance against the existence and activities of foreigners, improving coordination between relevant agencies especially the police force, providing foreign language courses, improve operational support facility. With an increase in the expected immigration officers can work more optimally;

2. Investigation action should more applied effectively in law enforcement against criminal acts of abuse of immigration permits. It is because of the existence of criminal sanctions is expected to cause effects deterrent to perpetrators and other foreigners so as not to do similar immigration crime;

3. Improve coordination and cooperation between relevant agencies;

4. Provide foreign language course other than english, so that Immigration Civil Servant Investigators is not a difficulty in evaluating against a foreigners;

5. Operational support facility should be increased so that more maximum Immigration Civil Servant Investigators performance in carrying out its work;

6. Increase capacity, professionalism and integrity in Immigration Civil Servant Investigators, through the enhancement of human resources in the form of seminars, symposiums, training technical investigation and coordination agency investigators. The existence of such activities, Immigration Civil Servant Investigators can be trained in completing each docket so that does not require a long time process of investigation;

7. Enhancing the role of the community by making a complaint about the existence or activities of the foreigners there were as well as socialization to society about the existence of Law of Republic of Indonesia Number 6 of 2011 concerning Immigration.

\section{REFERENCES}

[1] H. B. Artono, M. Alvi Syahrin, "Legal Impacts of The Existence of Refugees and Asylum Seekers in Indonesia," IJCIET, vol. 9, no. 5, pp. 1051-1058, 2018.

[2] Hendra Halwani, Ekonomi Internasional \& Globalisasi Ekonomi. Bogor: Ghalia Indonesia, 2005

[3] H. J. Berman, Latar Belakang Sejarah Hukum Amerika Serikat, dalam Talks on American Law, Random House, Inc., Indonesian Edition, Lectures about Unites States of America Law, Translated by Gregory Churchill. Jakarta: PT. Tatanusa, 1996.

[4] M. A. Syahrin, E-Commerce: Pilihan Hukum dan Pilihan Forum. Mahara Publishing, 2017.

[5] M. I. Santoso, Perspektif Imigrasi dalam United Nation Convention Against transational Organized Crime. Jakarta: Perum Percetakan Negara RI, 2007.

[6] M. A. Syahrin, "The Implementation of Non-Refoulement Principle to the Asylum Seekers and Refugees in Indonesia," Sriwij. Law Rev., vol. 1, no. 2, pp. 168-178, 2017.

[7] K. H. Ramadhan and Y. Abrar, Lintas Sejarah Imigrasi Indonesia. Jakarta: Direktorat Jenderal Imigrasi, 2005.

[8] A. Sjahriful, Memperkenalkan Hukum Keimigrasian. Jakarta: Ghalia Indonesia, 1993.

[9] M. A. Syahrin, Konsep Teoretis Penyelesaian Sengketa Hukum ECommerce. Mahara Publishing, 2017.

[10] P. M. Marzuki, Penelitian Hukum. Jakarta: Kencana Prenada Media 
Group, 2005.

[11] Y. B. Ardhiswastra, Penafsiran dan Konstruksi Hukum. Bandung Alumni, 2008.

[12] S. P. Panjaitan, Dasar-Dasar Ilmu Hukum: Asas, Pengertian, dan Sistematika. Palembang: Sriwijaya University, 1998.

[13] C.S.T. Kansil, Pengantar Ilmu Hukum dan Tata Hukum Indonesia. Jakarta: Balai Pustaka, 2002.

[14] S. Rahardjo, Masalah Penegakan Hukum. Bandung: Sinar Baru, 1983.

[15] Soerjono Soekanto, Faktor-Faktor yang Mempengaruhi Penegakan Hukum. Jakarta: Rajawali, 1983.

[16] M. I. Santoso, Perspektif Imigrasi Dalam Pembangunan Ekonomi dan Ketahanan Nasional. Jakarta: Universitas Indonesia (UI Press), 2004.

[17] M. A. Syahrin, "Imigran Ilegal dan HAM Universal," Bhumi Pura, vol. 5, no. 1, pp. 29-34, 2017.

[18] M. A. Syahrin, “Actio Pauliana: Konsep Hukum dan Problematikanya," Lex Libr. J. Ilmu Huk., vol. 4, no. 1, 2017.

[19] M. A. Syahrin, "Eksodus Warga Negara Tiongkok: Antara Kebijakan dan Penyelundupan," Bhumi Pura, vol. 6, no. 1, pp. 3840, 2016.

[20] M. A. Fahroy, C.A. and Syahrin, "Antara Batas Imajiner dan Kedaulatan Negara," Imigrasi di Batas Imajiner, Jakarta Kant. Imigrasi Kelas I Khusus Soekarno Hatta, 2016.

[21] M. A. Syahrin, “Aspek Hukum Laboratorium Forensik Keimigrasian: Studi Kasus Pemeriksaan Paspor Palsu Kebangsaan Inggris atas nama Abbas Tauqeer," Akta Yudisia, vol. 3, no. 1, 2018.
[22] M. A. Syahrin, "Penyadapan oleh Australia, Saatnya Imigrasi Bersikap,” Bhumi Pura, vol. 1, no. 1, pp. 30-35, 2014.

[23] M. A. Syahrin, "Menakar Kedaulatan Negara dalam Perspektif Keimigrasian,” J. Penelit. Huk. Jure, vol. 18, no. 1, pp. 43-57, 2018.

[24] M. Abdul Kholiq, Buku Pedoman Kuliah Hukum Pidana. Yogyakarta: Fakultas Hukum UII, 2002.

[25] Moeljatno, Azas-azas Hukum Pidana. Jakarta: Rineka Cipta, 2005.

[26] Muladi and Barda Nawawi Arief, Teori-teori dan Kebijakan Pidana. Bandung: Alumni, 1998

[27] M. A. Syahrin, "Pembatasan Prinsip Non-Refoulement," Bhumi Pura, vol. 1, no. 1, pp. 12-16, 2018.

[28] M. A. Syahrin, "Refleksi Teoretik E-Contract: Hukum yang Berlaku dalam Sengketa Transaksi Bisnis Internasional yang Menggunakan E-Commerce," Lex Libr. J. Ilmu Huk., vol. 3, no. 2, 2017.

[29] M. A. Syahrin, "Imigran Ilegal, Migrasi atau Ekspansi?," Checkpoint, vol. 3, no. 1, pp. 29-31, 2015.

[30] Moh Arif, Keimigrasian di Indonesia, Suatu Pengantar. Jakarta: Pusdiklat Departemen Kehakiman, 1997, p. 21.

[31] M. A. Syahrin, "Hak Asasi Bermigrasi," Bhumi Pura, vol. 11, no. 1, pp. 45-48, 2015

[32] M. A. Syahrin, "Jus Cogens dalam Protokol Penyelundupan Migran Tahun 2000,” Bhumi Pura, vol. 2, no. 1, pp. 13-16, 2018.

[33] M. A. Syahrin, "Penerapan Hukum Deteni Tanpa Kewarganegaraan (Stateless) yang Ditahan Lebih Dari 10 (Sepuluh) Tahun di Rumah Detensi Imigrasi Jakarta," Fiat Justicia, vol. 3, no. 2, 2017. 